\title{
Kreowanie wizerunku biblioteki akademickiej na podstawie działań public relations Biblioteki Politechniki Wrocławskiej
}

Streszczenie. Dążenie do budowy pozytywnego wizerunku dotyczy nie tylko przedsiębiorstw czy firm komercyjnych. Budowanie relacji z otoczeniem nabiera coraz większego znaczenia w instytucjach non profit, do których zaliczane są między innymi biblioteki. Celem artykułu jest przedstawienie działań promocyjnych realizowanych w bibliotece akademickiej. Na wstępie omówiono podstawowe pojęcia związane $\mathrm{z}$ public relations i wizerunkiem. Posłużono się przykładem Biblioteki Politechniki Wrocławskiej, która od wielu lat z pozytywnym skutkiem stosuje różnorodne techniki public relations. Bibliotekę czekają nowe wyzwania w związku ze zbliżającym się w 2013 roku terminem zakończenia budowy Środowiskowej Biblioteki Nauk Ścisłych i Technicznych na potrzeby Innowacyjnej Gospodarki - pierwszej w Polsce biblioteki oferującej zasoby wyłącznie w formie elektronicznej.

SŁowA KLuczowe: marka, promocja, tożsamość, biblioteka akademicka, komunikacja społeczna.

\section{Public relations}

Dbanie o dobrą opinię nie jest domeną wyłącznie naszych czasów. Ludziom od zawsze zależało na tym, aby o efektach ich pracy i sferach działalności oraz o nich samych mówiono dobrze. Panowało i nadal panuje powszechne przekonanie, że dobra reputacja jest gwarancją powodzenia i sukcesu. Stwierdzenie to odnosi się zarówno do jednostki, jak i do różnego rodzaju organizacji. Co ważne, to nie tylko wizerunek oraz praca sama w sobie mają bezpośredni wpływ na opinię, ale także, a może przede wszystkim, właściwa informacja. Pozytywne efekty przekazu wiadomości są możliwe tylko wtedy, gdy informacje są rzetelne i zgodne z rzeczywistością. 
Próby kształtowania opinii publicznej zaczęły pojawiać się wraz z tworzeniem się zorganizowanego społeczeństwa. Podczas procesu komunikowania się wiadomości nierzadko zmieniały się bądź wzbogacane były w dodatkowy kontekst. Do formowania opinii publicznej wykorzystywano także perswazję, służyła ona interesom rządzących. Za miejsce kształtowania opinii uważana była sławna w starożytnej Grecji wyrocznia w Delfach. Jej znaczenie było tak wielkie, że przepowiednie, które tam wygłaszano, miały znaczący wpływ na religię, politykę i prawa starożytnego państwa ${ }^{1}$. Miejscem zdobywania i wymiany informacji były grecka agora i rzymskie forum, gdzie zawodowi „nowinkarze” puszczali w obieg sensacyjne i nie zawsze wiarygodne informacje oraz własne opinie. Po całym świecie z wiadomościami przemieszczali się gońcy: w Chinach i w Rzymie - pomiędzy stacjami w formie zorganizowanej sztafety, w państwie Inków - w specjalnych strojach służbowych, które nakazywały każdemu udzielanie im pomocy. Informacje przekazywane ustnie musiały być zapamiętane przez uczestnika sztafety, który przekazał je dalej. Sztafety w Rzymie były tak dobrze zorganizowane, że umożliwiały efektywne rządzenie wielkim państwem.

Poza rządowym systemem przekazu informacji rozwijały się także inne formy kształtowania opinii. Przede wszystkim wprowadzały je duże firmy handlowe i banki. W średniowieczu domy kupieckie $w$ miarę regularnie wydawały gazety $\mathrm{z}$ informacjami handlowymi. Z czasem również rozszerzyły one obszar zainteresowań na informacje pozahandlowe, które dzisiaj można by określić mianem tzw. custom publishing. Wiadomości krążyły także w sferach kościelnych. Były one dostępne jednak tylko dla wtajemniczonych. Kościół od początku dbał o sprawną łączność ze wszystkimi diecezjami dzięki między innymi własnej poczcie. We Francji ukazywała się "Gazette" - pierwsze czasopismo francuskie, informujące o wydarzeniach na dworze, w dyplomacji i w polityce międzynarodowej. Na początku XVII wieku w Niemczech wydawano tygodnik kupiecki służący do wymiany informacji między kupcami i nabywcami ich towarów ${ }^{2}$. Wyżej wymienione przykłady wynikały bardziej z potrzeby komunikowania się niż z zaplanowanego, kontrolowanego działania.

Sformułowania "public relations" (PR - z ang. w dosłownym tłumaczeniu „publiczne relacje”) po raz pierwszy użył w 1787 roku Thomas Jefferson, prezydent USA, prawnik i działacz niepodległościowy. Jednak dopiero w latach 20. XX wieku zaczęto stosować ten termin w obecnym znaczeniu.

1 Wyrocznia delficka, w: Wikipedia. Wolna encyklopedia [online], [dostęp: 20.01.2013], dostępny w internecie: http://pl.wikipedia.org/wiki/Wyrocznia_delficka.

2 K. Wojcik, Public realations od A do Z, t. 1, wyd. 2 rozszerz. i zm., Warszawa 2001, s. 156. 
Pierwszym wykładowcą PR i autorem przełomowej książki Crystallizing public opinion, opublikowanej w Nowym Jorku w 1923 roku, był Edward L. Bernays $^{3}$. Stwierdził on, że „PR to dostarczanie (społeczeństwu) informacji, perswadowanie skierowane na zbliżenie postaw i działań organizacji do nastawienia klientów, a postaw klientów do nastawienia instytucji" ${ }^{4}$.

W Polsce początki PR przypadają na lata 90. XX wieku. W tym czasie zaczęły powstawać pierwsze agencje PR, a firmy zwróciły uwagę na konieczność zatrudniania specjalistów od spraw wizerunku. Dlatego też na wielu polskich wyższych uczelniach powstawały wydziały kształcące takich pracowników. Uczelnia, na której odbyły się pierwsze wykłady $\mathrm{z}$ tej dziedziny, był Uniwersytet Jagielloński. PR jako przedmiot akademicki jest wykładany głównie na uczelniach ekonomicznych. W 1994 roku powstało Polskie Stowarzyszenie Public Relations, którego inicjatorami byli Alma Kadragic i Piotr Czarnowski. Po dwóch latach działalności organizacja przyczyniła się do powstania Kodeksu Etycznego PR 5 . Ten zbiór wytycznych określał zasady, których powinien przestrzegać każdy PR-owiec, aby dobrze - w zgodzie ze standardami zawodu - wypełniać swoje zadania. W Polsce powszechnie używaną nazwą jest „pijar" lub „piar”, potoczny wariant, który powstał od zbitki dźwiękowej skrótu PR, czytanego zgodnie z wymową angielską [pi'ar] $]^{6}$.

PR jest dzisiaj jedną $z$ najszybciej rozwijających się dziedzin. Termin ten doczekał się ponad 2000 oficjalnych definicji ${ }^{7}$, które znacząco zmieniały się na przestrzeni ostatnich kilkudziesięciu lat w zależności od punktu widzenia. Początkowo PR traktowano jako wpływ na środowisko zewnętrzne, później włączono $\mathrm{w}$ zakres oddziaływania również wewnętrzną stronę organizacji. W Nowym leksykonie PWN termin ten potraktowany jest w kontekście socjologicznym:

Public relations - ogół ustosunkowań (opinii, postaw, poglądów) szerokich kręgów społecznych dotyczących działalności danej instytucji, organizacji, jeden z głównych celów planowej akcji propagandowej i reklamowej8.

3 E.L. Bernays, Crystallizing public opinion, New York 1923.

4 Ibidem. Cyt. za: K. Wojcik, Public relations: wiarygodny dialog z otoczeniem, wyd. 4 zm. i rozszerz., Warszawa 2009, s. 26.

5 O stowarzyszeniu: Historia, w: Polskie Stowarzyszenie Public Relations [online], [dostęp: 20.01.2013], dostępny w internecie: http://www.polskipr.pl/o-stowarzyszeniu/ historia/.

6 Pijarowski, w: Poradnia językowa [online], [dostęp: 20.01.2013], dostępny w internecie: http://poradnia.pwn.pl/lista.php?id=10848.

7 W. Budzyński, Public relations: zarzadzanie reputacja firmy, Warszawa 1998, s. 9.

8 Public Relations, w: Nowy leksykon PWN, Warszawa 1998, s. 1426. 
Krystyna Wojcik, autorytet PR w Polsce, podaje następującą definicję:

Public relations jest świadomym, celowym, planowym, systematycznym i długoplanowym oddziaływaniem organizacji, władz, zrzeszeń na publiczność, zwaną otoczeniem, skierowanym na ukształtowanie z nią specyficznej jakości stosunków i układów przy użyciu komunikowania i pielęgnowania kontaktów jako jedynej, klasycznej metody, i podporządkowanie tych wpływów rygorom etycznym 9 .

Najogólniej ujmując, podstawowym celem PR jest tworzenie pozytywnego wizerunku danej organizacji przez szereg działań komunikacyjnych.

Podczas komunikowania wykorzystuje się różnorodne techniki PR. Są to między innymi:

- słowo drukowane - własne publikacje, poradniki, broszury, informatory dla pracowników, ulotki, gazety, czasopisma zakładowe, sprawozdania, wydawnictwa jubileuszowe, książki opisujące historię organizacji, ogłoszenia, druki na specjalne okazje, informacje przeznaczone dla nowo zatrudnionych pracowników,

- słowo pisane - tablice ogłoszeń, witryny firmowe,

- słowo mówione - seminaria, szkolenia, indywidualne i grupowe rozmowy, punkty konsultacyjne i doradztwa,

- obraz - wystawy zakładowe, przedstawianie w formie graficznej informacji o organizacji (w pomieszczeniach firmy),

- oddziaływanie przez imprezy informacyjne - zwiedzanie firmy, jej urządzeń, oprowadzanie zwiedzających gości, imprezy jubileuszowe, narady pracownicze, imprezy informacyjne podczas targów, członkostwo przedstawicieli w organizacjach o uznanym autorytecie społecznym ${ }^{10}$.

\section{Wewnętrzny i zewnętrzny PR}

Działania PR podejmowane w firmie muszą być starannie przemyślane, tak aby obejmowały zarówno organizację, jak i jej otoczenie. Budowa dobrych relacji z otoczeniem zaczyna się od dobrego wizerunku wewnętrznego, czyli w samej instytucji - wśród jej pracowników. PR wewnętrzny to jeden z ważniejszych obszarów dotyczący „środowiska

9 K. Wojcik, Public Relations, w: Encyklopedia biznesu, red. W. Pomykało, t. 2, Warszawa 1995, s. 740 .

${ }^{10}$ Ibidem, s. 103-106. 
wewnętrznego" organizacji. Techniki PR wewnętrznego powinny być dobierane w zależności od wielkości i możliwości organizacji. W sprawnie działającym PR wewnętrznym podstawą jest skuteczna informacja.

PR zewnętrzny ma na celu komunikację instytucji ze światem zewnętrznym. Są to wszystkie informacje przekazywane przez organizację. Warto podkreślić, że nie tylko specjaliści od PR są odpowiedzialni za tworzenie pożądanego wizerunku instytucji. Duże znaczenie mają także bezpośrednie kontakty z klientami i osobami odwiedzającymi instytucję. Relacje te budowane są w sposób ciągły każdego dnia i jeśli są one niewłaściwe, to nawet najlepsza kampania przygotowana przez specjalistów od PR nie przyniesie długotrwałych pozytywnych skutków.

\section{Wizerunek i tożsamość}

Wizerunek to cel, efekt realizacji zadań ${ }^{11}$, sposób, w jaki osoba lub rzecz jest postrzegana i przedstawiana ${ }^{12}$. Termin „,wizerunek” może także odnosić się do całej firmy, pozwala na jej jednoznaczną identyfikację taki wizerunek buduje się $\mathrm{W}$ odniesieniu do grupy odbiorców ${ }^{13}$.

Wizerunek jest najczęściej obrazem nierzeczywistym, łączącym różne detale zaobserwowane przypadkowo. Na ten obraz składają się takie elementy jak wygląd, zachowanie, zapach, a także opinie innych, którzy być może wcześniej mieli do czynienia z produktem, marką lub instytucją. Jest to czynnik niematerialny, zależny od percepcji innych, od ich spostrzegawczości i oceny, od wrażliwości na różnego rodzaju bodźce, jakie dostarczane są przez cechy indywidualne. To wyobrażenie istniejące w bezpośrednim otoczeniu, głównie u klientów, obejmujące zbiór pozytywnych skojarzeń wywoływanych po usłyszeniu nazwy firmy lub ujrzeniu jej znaku graficznego ${ }^{14}$. Przy czym wyobrażenie to nie musi pokrywać się z rzeczywistościa, może być jedynie subiektywnym obrazem przedsiębiorstwa lub jego oferty.

${ }^{11}$ K. Bakalarski, Public relations a ksztattowanie wizerunku menedżera, Gdańsk 2004, s. 41 .

${ }^{12}$ Wizerunek, w: Stownik języka polskiego [online], [dostęp: 20.01.2013], dostępny w internecie: http://sjp.pwn.pl/haslo.php?id=2579940.

${ }^{13}$ Wizerunek, w: Wikipedia. Wolna encyklopedia [online], [dostęp: 20.01.2013], dostępny w internecie: http://pl.wikipedia.org/wiki/Wizerunek.

${ }^{14}$ Wizerunek firmy, w: Wikipedia. Wolna encyklopedia [online], [dostęp: 20.01.2013], dostępny w internecie: http://pl.wikipedia.org/wiki/Wizerunek_firmy. 
Takiego wizerunku nie możemy dowolnie zmieniać, mamy jedynie możliwość zarządzania nim przez systematyczne działania, zgodnie z następującymi założeniami:

- wyróżnienie spośród ogółu konkurentów, czyli konsekwentne prezentowanie własnej tożsamości,

- precyzyjne określenie wartości i pozycji na rynku,

- prezentowanie indywidualnego charakteru,

- angażowanie wszystkich pracowników w realizację wspólnej wizji i stawianych celów ${ }^{15}$.

Wizerunek często traktowany jest jako synonim pojęcia "tożsamość". Wojciech Budzyński precyzuje oba terminy, dokładnie je rozróżniając:

Wizerunek przedsiębiorstwa jest jego obrazem wśród ludzi, którzy się z nim spotykają - klientów, kontrahentów, urzędników, pracowników i innych. Inaczej - jest on tym, co ludzie myślą o przedsiębiorstwie. Tożsamość zaś jest sumą elementów, które identyfikują je, wyróżniając spośród innych przedsiębiorstw. Wyraża się ona w jego indywidualnym charakterze w formie wizualnej ${ }^{16}$.

Inaczej mówiąc, jest to odbicie tożsamości w świadomości odbiorców. Tożsamość to świadomość organizacji, a wizerunek to jej obraz i konsekwencja ${ }^{17}$. Elementy tożsamości muszą:

- odpowiadać specyfice organizacji,

- być łatwe do zapamiętania,

- wyróżniać się wśród innych,

- być wolne od niekorzystnych skojarzeń,

- mieć możliwość łatwej adaptacji do różnych technik public relations,

- rzucać się w oczy ${ }^{18}$.

Wizerunek może być kreowany i kształtowany na różne sposoby i z różnym skutkiem. Kreowanie wizerunku, zarówno osobistego, jak również dotyczącego produktów, usług, zachowań czy wręcz całego przedsiębiorstwa, to działanie niezwykle złożone. Wymaga przemyślanych, profesjonalnych zachowań. Długoterminowe, strategiczne planowanie PR daje znacznie lepsze efekty niż wiele niespójnych działań. Przy czym bardzo ważne jest, aby nie zatracić celu, który został ustalony na

15 P. Misiurski, Dlaczego wizerunek jest ważny? [online], [dostęp: 20.01.2013], dostępny w internecie: www.ember.pl/marka11.php.

${ }^{16}$ W. Budzyński, op,cit., s. 73.

17 P. Misiurski, op.cit.

${ }^{18}$ W. Budzyński, op,cit., s. 74. 
samym początku. Dlatego też działania PR powinny mieć solidne podstawy. Wstępne czynności powinny polegać na dokładnej ocenie obecnego wizerunku i sporządzeniu planu usunięcia słabych punktów, a następnie konsekwentnym dążeniu do wyznaczonych celów oraz koncentracji na tym, co, jak i kiedy chce się osiągnąć. Bardzo ważne jest także ciągłe śledzenie postępów i ocena cząstkowych efektów.

\section{Public relations $\mathrm{w}$ bibliotece}

Koncepcja skutecznych działań PR jako istotnego składnika dobrego zarządzania biblioteką nie jest czymś nowym. Z początkiem lat 70 . większość bibliotek publicznych w USA wdrożyła niektóre strategie PR w stosunku do swoich użytkowników, członków społeczności i władz ${ }^{19}$. Początkowo działo się to jedynie w bibliotekach publicznych, jednak $\mathrm{w}$ późniejszym okresie dostrzeżono znaczenie PR również $\mathrm{w}$ innych typach bibliotek.

Istotny wpływ na kształtowanie wizerunku mają odpowiednio prowadzone działania PR w kontaktach $\mathrm{z}$ mediami, tj. prasa, telewizja, radiem, a także, a może przede wszystkim, w przypadku organizacji niekomercyjnych, wykorzystywanie własnych możliwości i narzędzi. Są to: strona internetowa oraz organizowanie różnego rodzaju działań promocyjnych, takich jak konferencje, szkolenia, wystawy, publikacja wydawnictw reklamowych.

W niniejszym artykule omówiono działania PR stosowane w Bibliotece Politechniki Wrocławskiej (PWr). Niemalże od początku istnienia (1946) Biblioteka PWr w różnorodnych formach promuje swoją działalność. Efekty tych poczynań widoczne są w środowisku lokalnym, a także na arenie ogólnopolskiej i międzynarodowej. Początkowo była to głównie działalność szkoleniowa i wydawnicza, później dołączono też: organizację konferencji, kursów, wystaw, udział w festiwalach nauki, targach książek, umożliwianie promocyjnych dostępów do źródeł elektronicznych, kontakt z mediami uczelnianymi, prezentacje na portalu internetowym oraz wiele innych technik PR. Ze względu na ograniczone możliwości w artykule podjęto próbę zaprezentowania tylko niektórych, wybranych przykładów aktywności promocyjnych podejmowanych i realizowanych przez Bibliotekę Politechniki Wrocławskiej, mających

${ }^{19}$ N. Marshall, Public relations in academic libraries: a descriptive analysis, „The Journal of Academic Librarianship" 2001, t. 27, nr 2, s. 116. 
na celu kształtowanie pozytywnego i trwałego wizerunku w oczach jej użytkowników.

\section{Identyfikacja wizualna}

Istotnym elementem wizerunku jest identyfikacja wizualna. Składa się na nią wszystko to, dzięki czemu można zidentyfikować organizację, czyli forma symboliczno-graficzna: logo, logotyp, czcionka używana na kopertach i drukach firmowych, identyfikatory, wizytówki, pieczątki. Najważniejszym elementem wizerunku jest nazwa, która stanowi główny nośnik tożsamości. Przedstawienie nazwy w postaci graficznej sprawia, że odbierana jest ona za pomocą więcej niż jednego zmysłu. Środkiem komunikowania silnie wpływającym na sferę emocjonalną odbiorcy są barwy. Pozwalają one lepiej zauważyć wypowiedź i zapamiętać jej treść ${ }^{20}$. Mają także ogromny wpływ na psychikę człowieka i wywołują pożądane efekty emocjonalne związane z wyborem produktu. Spójny system wizualny, konsekwencja oraz dbałość o szczegóły to najważniejsze elementy całościowej identyfikacji.

Biblioteka Główna (BG) wchodząca w strukturę Politechniki Wrocławskiej jako jednostka ogólnouczelniana rozpoczęła wdrażanie Systemu Identyfikacji Wizualnej (SIW) na podstawie Zarządzenia wewnętrznego nr 57/2004 ${ }^{21}$ wydanego przez ówczesnego rektora prof. Tadeusza Lutego. W księdze SIW określone zostały zasady stosowania znaku graficznego PWr (standardy i dopuszczalne modyfikacje), obowiązujące liternictwo i kolorystyka oraz wzory podstawowych dokumentów PWr, takie jak: papier firmowy, koperta, faks, prezentacja, wizytówka, naklejka adresowa, wydawnictwa wewnętrzne (regulaminy, skrypty), prace dyplomowe. $W$ celu ochrony przed niewłaściwym użyciem znak PWr został zastrzeżony w Urzędzie Patentowym RP. Wszystkie jednostki organizacyjne PWr stosują się do zaleceń zawartych w opracowaniu SIW, którego celem było zbudowanie rozpoznawalnego wizerunku uczelni ${ }^{22}$.

${ }^{20}$ K. Wojcik, Public Relations, s. 80.

${ }^{21}$ Zarzadzenie wewnętrzne 57/2004 w sprawie wprowadzenia Systemu Identyfikacji Wizualnej Politechniki Wrocławskiej [online], [dostęp: 20.01.2013], dostępny w internecie: http://www.logotyp.pwr.wroc.pl/Default.aspx?page=ZarzadzenieRektora.

${ }^{22}$ Identyfikacja wizualna [online], [dostęp: 20.01.2013], dostępny w internecie: http:// www.logotyp.pwr.wroc.pl/Default.aspx?page=Main. 


\section{Witryna Biblioteki PWr}

Pozytywny wizerunek można budować w różny sposób i przy użyciu wielu różnorodnych narzędzi. Jednym z nich jest strona internetowa, która jest obecnie najsprawniej działającą wizytówką firmy w świecie wirtualnym. Jej ogólne wrażenie wizualne, struktura, a przede wszystkim intuicyjna nawigacja mogą mieć wpływ na dalszy kontakt pomiędzy odbiorcą a właścicielem portalu internetowego.

Jak podaje Michał Łebkowski, „strona WWW może mieć największy wpływ na wizerunek firmy, ponieważ nie narzucając się klientowi, informuje go o każdej rzeczy, o jakiej ten chce się dowiedzieć" ${ }^{23}$. Autor wymienia trzy filary dobrej strony internetowej:

- łatwo do niej trafić (dzięki łatwemu do zapamiętania adresowi lub dzięki wyświetlaniu się $\mathrm{w}$ wyszukiwarkach na wysokich pozycjach),

- jest zrobiona estetycznie, przyjemnie dla oka, najlepiej z takim elementem, który zapada w pamięć,

- nawigacja na niej nie sprawia kłopotów ${ }^{24}$.

Zgodnie z zasadami zawartymi w księdze SIW w grudniu 2009 roku powstał nowy, jednolity portal PWr, a w jego obrębie serwisy poszczególnych jednostek, w tym także serwis BG. Obowiązują w nim identyczny krój czcionki i identyczna kolorystyka - poszczególnym wydziałom oraz innym jednostkom organizacyjnym PWr przypisano różne kolory. W całym portalu PWr obowiązuje ten sam schemat - strona główna podzielona jest na trzy zasadnicze części. Środkowa - „Aktualności” - obudowana jest po prawej i po lewej boksami, wspomagającymi korzystanie z danej strony pod względem nawigacyjnym i informacyjnym, takimi jak: "Na skróty”, „Kontakt”, „Interaktywna mapa kampusu”, „Teleporter”, „Czy wiesz, że...", „Newsletter" oraz „Wydarzenia”.

Do zarządzania stronami w portalu internetowym PWr zastosowano system CMS (ang. content management system), który umożliwia prostą obsługę interfejsu użytkownika - tworzenie, aktualizację i rozbudowę serwisu WWW.

Struktura i układ treści zawarty w części portalu należącej do Biblioteki PWr zostały zorganizowane podobnie jak poprzedni serwis, którego funkcje i rola były starannie przemyślane pod kątem grupy docelowej

${ }^{23}$ M. Łebkowski, E-wizerunek. Internet jako narzędzie kreowania image'u w biznesie [online], [dostęp: 20.01.2013], dostępny w internecie: http://www.structum.pl/czytelnia/E-wizerunek-Internet-jako-narzedzie-kreowania-image-u-w-biznesie.pdf.

${ }^{24}$ Ibidem. 
odbiorców, czyli głównie studentów i pracowników Politechniki Wrocławskiej. Zastosowane rozwiązania umożliwiły między innymi utrzymanie jednolitego stylu prezentacji, prostą i łatwą nawigację oraz sprawne zarządzanie zawartością portalu. Strona biblioteki jest na bieżąco aktualizowana i rozbudowywana. W kolumnie „Aktualności” systematycznie pojawiają się wiadomości dotyczące testowania nowych baz, dostępu do e-źródeł oraz informacje o szkoleniach i innych ciekawych wydarzeniach w bibliotece. Warto podkreślić dbałość o zamieszczanie nowych treści. Są one każdorazowo oglądane i sprawdzane w najpopularniejszych przeglądarkach (tj. Mozilla Firefox, Opera, Google Chrom, Internet Explorer), ponieważ zasady działania przeglądarek mogą różnić się między sobą i w konsekwencji zamieszczone na stronie informacje mogłyby być zaprezentowane w sposób niepożądany. Zawartość poszczególnych filtrów (tj. usługi, e-książki, bazy danych, e-czasopisma) objęta jest opieką merytoryczną wyznaczonych osób, które mają zgłaszać nieprawidłowości i przygotowywać aktualizacje.

We wrześniu 2012 roku na stronie głównej biblioteki zostało zamieszczone okno multiwyszukiwarki umożliwiające jednoczesne przeszukiwanie wielu zasobów informacyjnych, takich jak: serwisy książek i czasopism elektronicznych, baz danych oraz katalogu bibliotecznego PWr. Korzystanie z multiwyszukiwarki jest możliwe na terenie Politechniki Wrocławskiej oraz zdalnie przez serwer PROXY25. Biblioteka PWr posiada także konta w kanałach komunikacyjnych, jakimi są serwisy społecznościowe: Facebook, Twitter i Google+.

W roku 2013 cały portal internetowy politechniki, a tym samym także strony należące do biblioteki czeka kolejna zmiana. Obecnie trwają prace przygotowawcze polegające na zebraniu i sformułowaniu założeń dla nowej wersji strony internetowej. Zakłada się między innymi, że administratorzy poszczególnych jednostek portalu PWr będą mieli większą swobodę we wprowadzaniu zmian w układzie graficznym. Przewiduje się także inny układ treści, aby jeszcze lepiej dostosować go do odbiorców środowiska uczelnianego z uwzględnieniem nowych użytkowników. Od nowego roku szkolnego 2013/2014 władze uczelni planują bowiem otworzyć przy politechnice Akademickie Liceum Ogólnokształcące i Gimnazjum Akademickie, które będą mieściły się w budynku C-13, popularnie nazywanym "serowcem”. Uczniowie będą korzystać z pracowni naukowych, laboratoriów, a także z Biblioteki PWr. Przygotowywane są nowe funkcjonalności, takie jak wersja mobilna strony internetowej biblioteki

${ }^{25}$ Usługa zdalnego dostępu do elektronicznych zasobów informacyjnych spoza uczelnianej sieci komputerowej po spełnieniu określonych warunków. 
umożliwiająca korzystanie z informacji zawartych na stronie za pomocą takich urządzeń jak telefony komórkowe, palmtopy, tablety.

\section{Współpraca z mediami i środowiskiem akademickim}

Dobre kontakty z mediami mogą mieć ogromne znaczenie podczas budowania zewnętrznego wizerunku firmy. Stała współpraca z dziennikarzami (media relations) stanowi najbardziej efektywną formę komunikacji. Wśród media relations można wyróżnić dwa rodzaje kontaktów: pisemne, czyli dostarczanie środkom masowego przekazu wypowiedzi w formie słowa pisanego, oraz bezpośrednie, czyli np. wywiad okolicznościowy, relacja telewizyjna $z$ imprezy, program radiowy. $W$ mediach informacje na temat bibliotek, jeżeli już się pojawiaja, to zazwyczaj w końcowej części programu informacyjnego. Niestety, jedną z najbardziej zaniedbanych dziedzin w relacjach bibliotek ze społeczeństwem są właśnie kontakty z mediami. Bibliotekarze powinni nie tylko wiedzieć, jak postępować $\mathrm{z}$ dziennikarzami, ale także brać udział w organizowaniu kampanii reklamowych i promocyjnych własnych bibliotek.

Informacje przekazywane społeczności akademickiej przez media uczelniane odgrywają ogromną rolę $\mathrm{w}$ budowaniu pozytywnego wizerunku biblioteki. Kilka razy w roku w miesięczniku uczelnianym PWr „Pryzmat” pracownicy biblioteki publikują artykuły i sprawozdania dotyczące różnych form aktywności i wydarzeń odbywających się w bibliotekach systemu biblioteczno-informacyjnego PWr. Krótkie komunikaty dotyczące między innymi testowania baz danych, szkoleń, prezentacji i wystaw organizowanych w bibliotekach PWr, nowości zamieszczonych w Dolnośląskiej Bibliotece Cyfrowej przesyłane są do biuletynów: eBIP (Elektroniczny Biuletyn Informacyjny Politechniki) oraz eStudent (Elektroniczny Biuletyn Informacyjny dla Studentów). Biuletyny te ukazują się co tydzień.

W Bibliotece PWr wyznaczeni pracownicy utrzymują stały kontakt z Działem Marketingu i Promocji, który jest odpowiedzialny za:

- promocję zewnętrzną uczelni (Wrocław, region, kraj, zagranica),

- inicjowanie i realizację działań promocyjnych,

- opracowywanie materiałów informacyjnych i promocyjnych na potrzeby ogólnouczelniane, z uwzględnieniem zapotrzebowania jednostek,

- opracowywanie danych do rankingów szkół wyższych, na podstawie informacji nadsyłanych przez jednostki Politechniki Wrocławskiej, 
- opiniowanie i monitorowanie użycia Sytemu Identyfikacji Wizualnej przez jednostki uczelni oraz partnerów zewnętrznych,

- organizację i obsługę w zakresie technicznym i logistycznym imprez, takich jak: konferencje, sympozja, kongresy, kursy, zjazdy, warsztaty naukowe, szkolenia, wystawy, uczelniane edycje DFN i inne imprezy organizowane przez Politechnikę Wrocławską w siedzibie uczelni ${ }^{26}$.

Upowszechniając działania PR, warto stosować pozytywny lobbing. W dążeniu do uzyskania przychylności władz, mediów i innych zainteresowanych obejmować on powinien różnorodne sfery aktywności i prowadzić do popularyzacji idei, zyskiwania sojuszników dla konkretnych celów. Artur Jazdon uważa, że

musimy sami docierać do posłów, radnych, członków senatów uczelnianych, aby dostarczać im wiedzy o naszych problemach i osiągnięciach oraz wpływać przede wszystkim na decyzje dotyczące naszych budżetów, lokali, przyłączy informatycznych. Bez tych przyziemnych, ale podstawowych spraw nie ma możliwości realizacji dużych zadań, które potrafimy i chcemy realizować ${ }^{27}$.

Lobbing [...] prowadzony zgodnie z pewnymi zasadami to przede wszystkim dostarczanie odpowiednich informacji - rzetelnej, dobrze opracowanej, analitycznej; to rzeczowe argumentowanie w celu przekonania, że dana decyzja przyniesie korzyści większości, a ewentualne skutki niekorzystne będą minimalne ${ }^{28}$.

Bezpośrednie kontakty bibliotekarzy w PWr ze środowiskiem akademickim mają charakter okresowy. Spotkania odbywają się między innymi z okazji zebrań członków Rady Bibliotecznej, w których uczestniczą: przedstawiciele senatu oraz doktorantów i studentów PWr, prorektor ds. badań naukowych i współpracy z gospodarka, kanclerz oraz dyrekcja i przedstawiciele różnych grup pracowników bibliotecznych. Poza ujętymi w programie tematami jest to okazja zarówno do promowania działalności biblioteki, jak i do sygnalizowania jej problemów.

Dyrektor Biblioteki Głównej jest uczestnikiem posiedzeń Senatu PWr z głosem doradczym. Temat biblioteki pojawia się na posiedzeniach

${ }^{26}$ Zadania Sekcji Promocji [online], [dostęp: 20.01.2013], dostępny w internecie: http://www.portal.pwr.wroc.pl/dzial_marketingu.dhtml.

${ }^{27}$ A. Jazdon, Lobbing dla bibliotek?, w: Public relations - biblioteki, wydawnictwa, informacja naukowa, uczelnie, red. M. Kocójowa, Kraków 2004, s. 43.

${ }^{28}$ Ibidem, s. 42. 
senatu przy różnych okazjach. W ostatnim czasie najczęściej w związku z budową nowego gmachu Środowiskowej Biblioteki Nauk Ścisłych i Technicznych na potrzeby Innowacyjnej Gospodarki. Dyrektor zabiera także głos w sprawach dotyczących całego systemu biblioteczno-informacyjnego PWr, Dolnośląskiej Biblioteki Cyfrowej, dorobku naukowego pracowników i innych. Z początkiem nowego roku kalendarzowego przedstawia on też sprawozdanie $\mathrm{z}$ działalności systemu biblioteczno-informacyjnego.

\section{Wydawnictwa}

Jedną z podstawowych form szerokiej komunikacji z otoczeniem stanowią wydawnictwa reklamowe. Dzięki nim można zaistnieć w świadomości odbiorców lub zwrócić uwagę na nowe produkty czy usługi. W Bibliotece PWr działalność wydawnicza znacząco rozwinęła się $\mathrm{w}$ latach $70{ }^{29}$, kiedy do profesjonalnego realizowania działalności edytorskiej biblioteki powołano agendę - Redakcję Wydawnictw Informacyjnych. Agenda ta została zlikwidowana z końcem 2010 roku, a zadania zostały przekazane do różnych oddziałów BG. W porównaniu z latami 70. i 80. działalność wydawnicza prowadzona jest w znacznie ograniczonym zakresie. Obecnie praca ta polega na przygotowywaniu publikacji książkowych, biuletynów, przewodników, plakatów, zakładek i różnego rodzaju ulotek prezentujących bibliotekę całościowo lub zwracających uwagę na konkretny temat, np.: książki i czasopisma elektroniczne, oferta usług informacyjnych, Dolnośląska Biblioteka Cyfrowa, baza DONA, ulotki okolicznościowe. Co kilka lat wspólnie z Działem Promocji i Marketingu PWr przygotowywany jest biuletyn o bibliotece (il. 1), w którym w ciekawej szacie graficznej, bogato ilustrowanej i zgodnej z Systemem Identyfikacji Wizualnej PWr, podana jest informacja o zbiorach, katalogach, usługach, dostępie do zasobów elektronicznych, historii biblioteki, agendach i strukturze organizacyjnej. Każdego roku publikowana jest w kilkutysięcznym nakładzie zaktualizowana wersja informatora dla studentów - System biblioteczno-informacyjny Politechniki Wrocławskiej. Dostępna jest ona w formacie PDF (także w wersji angielskiej) $\mathrm{w}$ internecie.

${ }^{29}$ B. Makarska-Deszcz, Działalność wydawnicza Biblioteki Politechniki Wrocławskiej, w: Biblioteka Politechniki Wrocławskiej 1946-2006, red. H. Szarski, J. Wojtczak, Wrocław 2007, s. 94. 


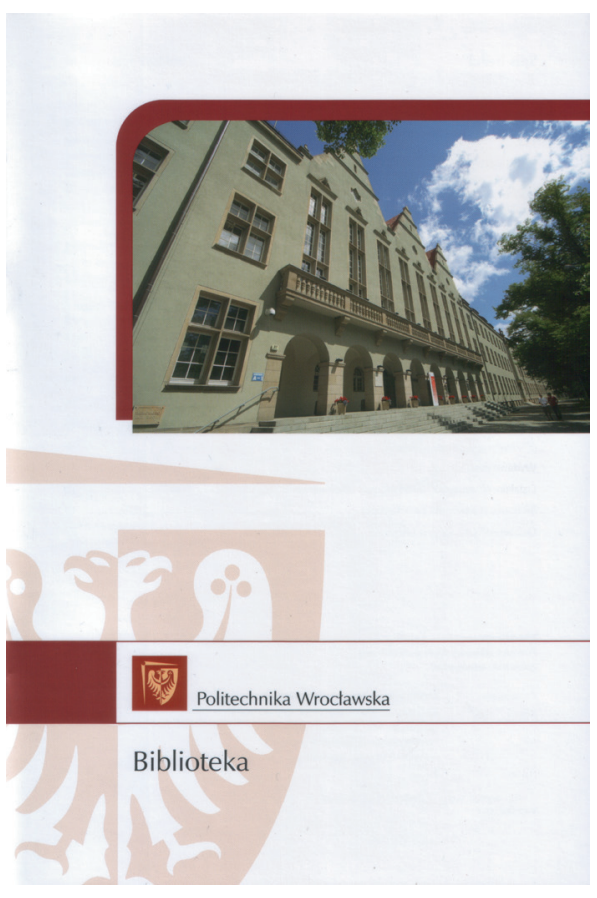

Il. 1. Biuletyn Biblioteka

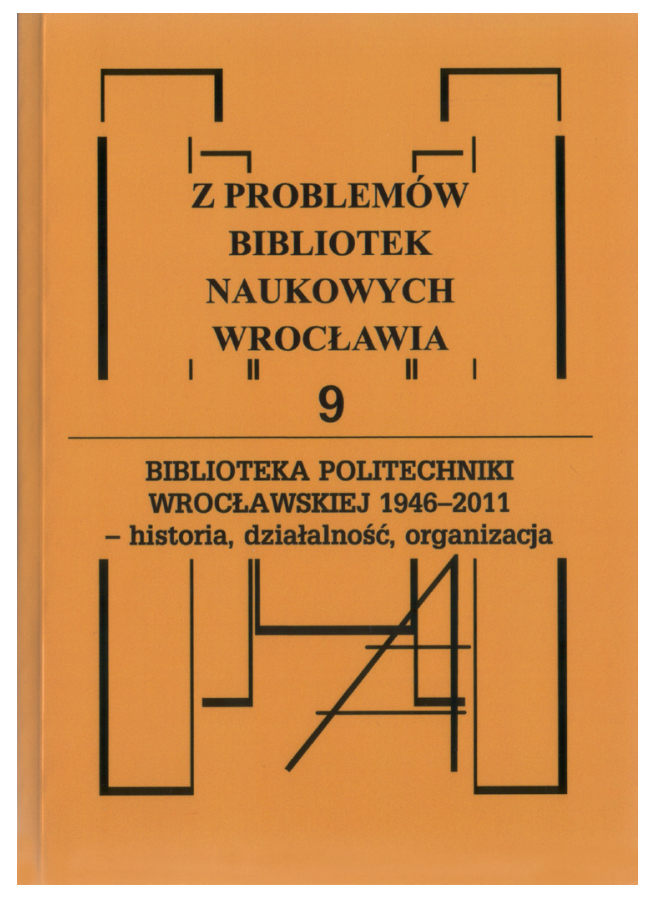

Il.2. Biblioteka PolitechnikiWroctawskiej1946-2011 - historia, działalność, organizacja

Dobry przykład stanowić mogą publikacje ujęte w serii wydawniczej „Z Problemów Bibliotek Naukowych Wrocławia". Do tej pory ukazały się dwa tomy serii w całości poświęcone Bibliotece PWr. Są to: tom 5 - Biblioteka Politechniki Wrocławskiej 1946-2006 oraz tom 9 - Biblioteka Politechniki Wrocławskiej 1946-2011 - historia, działalność, organizacja (il. 2). Pretekstem do ich powstania były okrągłe rocznice 60- i 65-lecia założenia Biblioteki PWr.

Związek z obchodzonymi w bibliotece kolejnymi jubileuszami mają także inne wydawnictwa okolicznościowe. Są one przeznaczone głównie do celów wewnętrznych. W roku 2011 ukazała się publikacja zatytułowana 65 lat Biblioteki Politechniki Wrocławskiej 1946-2011 (il. 3.), zawierająca kalendarium najważniejszych wydarzeń, nazwiska dyrektorów Biblioteki Głównej - od początku istnienia do chwili obecnej - kadrę kierowniczą BG i pozostałych bibliotek funkcjonujących w PWr oraz listę pracowników zatrudnionych w systemie biblioteczno-informacyjnym dłużej niż rok.

Jeszcze inny przykład opracowania o charakterze wewnętrznym stanowić może wydawnictwo „Lektury Bibliotekarza, czyli praktyczny przegląd piśmiennictwa bibliotekarskiego i nie tylko" (il. 4). Jest ono przygotowywane cztery razy w roku (co kwartał). Znajdują się w nim 


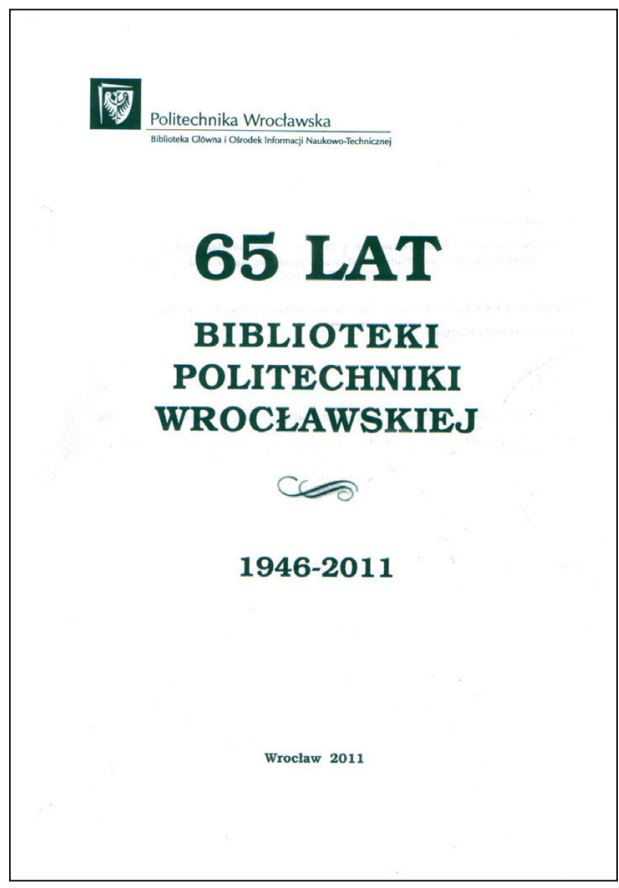

Il. 3. 65 lat Biblioteki Politechniki Wroctawskiej

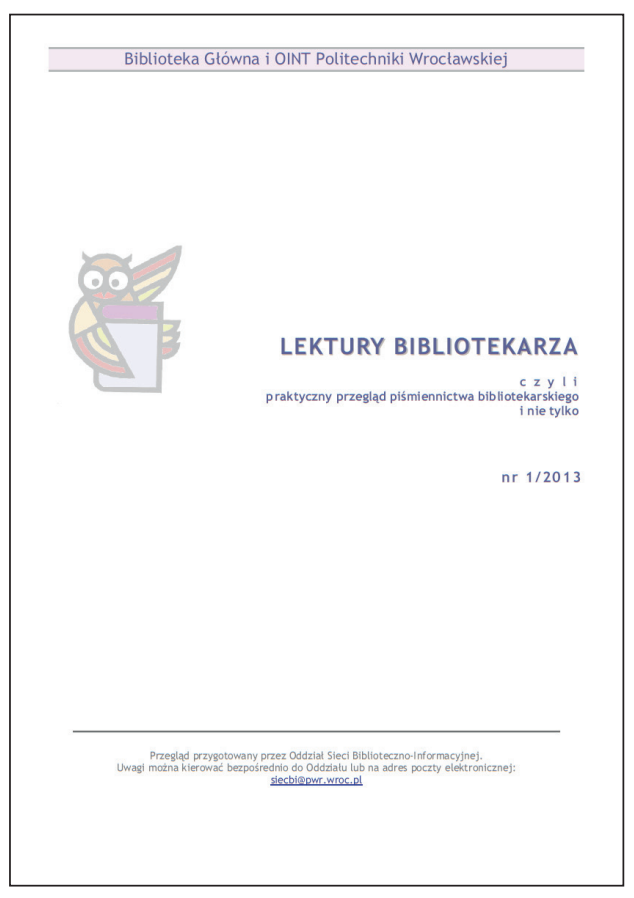

Il. 4. „Lektury Bibliotekarza”

spisy treści fachowych czasopism prenumerowanych przez bibliotekę i dostępnych w Czytelni Głównej. Poszczególne pozycje uzupełnione są aktywnymi linkami do wersji elektronicznej pełnotekstowej lub internetowej. Pracownicy Biblioteki PWr w ostatnich latach coraz częściej i chętniej publikują na łamach tych periodyków, w związku z tym artykuły przez nich napisane są wyróżnione innym kolorem czcionki. „Lektury Bibliotekarza” wzbogacone są także w informacje na temat nowych książek z dziedziny bibliotekarstwa, bibliotekoznawstwa, księgarstwa i archiwistyki oraz dokumentacji i informacji naukowej. Od kilku lat wydawnictwo przygotowywane jest w wersji PDF i przesyłane pocztą elektroniczną. Do niedawna przegląd wysyłany był tylko do młodych pracowników oraz osób zainteresowanych. Obecnie odbiorcami są wszyscy pracownicy systemu biblioteczno-informacyjnego PWr. 


\section{Wystawy}

Kolejnym ważnym elementem PR jest wystawa. Kreuje ona wizerunek i utrwala pozytywne oddziaływanie danej instytucji na środowisko. Informacja o wystawie w mediach oraz wydźwięk społeczny po jej otwarciu przywołują pozytywne skojarzenia na temat firmy. Dobrze zorganizowana wystawa umacnia obiektywne i rzetelne informacje o firmie przekazane opinii publicznej.

W 2010 roku z okazji 65-lecia Politechniki Wrocławskiej oraz 100-lecia Uczelni Technicznych we Wrocławiu pracownicy BG przygotowali wystawę "Z Biblioteką Politechniki Wrocławskiej przez stulecie”. Oprócz zaprezentowanych cennych zbiorów biblioteki można było zapoznać się z jej bogatą historią oraz przyszłością bibliotek związaną z digitalizacją i technologia papieru elektronicznego. Elementem promującym wystawę, oprócz plakatów i ulotek, były prezentacja i zaproszenie na wystawę, która w sposób ciągły ukazywała się na monitorach znajdujących się w holu głównym politechniki przez cały czas trwania ekspozycji. Wystawa cieszyła się bardzo dużym zainteresowaniem. Była odwiedzana przez studentów i pracowników uczelni, osoby z zewnątrz, w tym liczne reprezentacje bibliotekarzy z kilku wrocławskich bibliotek. Na jej otwarcie zaproszeni zostali emerytowani pracownicy biblioteki, którzy zainteresowani byli zwłaszcza częścią historyczną.

Kilka razy w roku w różnych miejscach PWr, głównie w bibliotekach wydziałowych, organizowane są wystawy książek. Przygotowują je pracownicy bibliotek uczelni oraz firmy prezentujące książki. Chętnie odwiedzane przez pracowników dydaktycznych, naukowych i studentów mają na celu typowanie zagranicznych książek do zakupu. Taki sposób kontaktowania się z użytkownikami jest sprawdzonym i skutecznym elementem promocji biblioteki.

\section{Konferencje, imprezy}

Tradycja organizowania konferencji przez Bibliotekę PWr sięga lat 70. Obecnie dużą popularnością cieszy się cykl międzynarodowych konferencji Wrocławskie Spotkania Bibliotekarzy, które w czerwcu 2013 roku będą miały już czwartą edycję. Uczestnikami spotkań są bibliotekarze z wielu państw, m.in. Kanady, USA, Argentyny, Szwecji, Holandii, Niemiec, Anglii, Litwy, Węgier, Macedonii oraz Polski. Można wyróżnić trzy bloki tematyczne: 1) biblioteka w uczelni i regionie, 2) źródła elektroniczne 
w bibliotece i na rynku, 3) dokumentowanie i analiza dorobku naukowego. Konferencja stanowi doskonałą promocję Wrocławia i Dolnego Śląska zarówno w Polsce, jak i poza granicami kraju. Bogaty program zdominowany jest przez referaty konferencyjne, ale nie brakuje ciekawostek, takich jak: zwiedzanie najważniejszych atrakcji Wrocławia i okolic, koncerty i spotkania z ciekawymi ludźmi. Honorowym gościem i czynnym uczestnikiem wszystkich edycji konferencji jest prof. Jan Miodek.

Biblioteka PWr, pierwsza w kraju, od początku istnienia Dolnośląskiego Festiwalu Nauki (1998) aktywnie uczestniczy w jego organizacji. Adresatami imprezy są głównie gimnazjaliści i młodzież uczęszczająca do liceów. U schyłku lat 90. tematy dotyczące internetu, takie jak „Polowanie na informację. Od książki do Internetu", dla większości młodych osób były prawdziwą nowością. Od 15 lat uczniowie szkół ponadpodstawowych z zaciekawieniem oglądają przygotowane wystawy i różnorodne prezentacje, słuchają wykładów i z bliska przyglądają się, jak powstaje Dolnośląska Biblioteka Cyfrowa. Zajęcia w ramach Dolnośląskich Festiwali Nauki odbywające się w poszczególnych uczelniach Wrocławia odgrywają bardzo ważną rolę promocyjną. W związku z faktem, że skierowane są do młodzieży szkolnej, nierzadko ich uczestnicy wybierają studia na poznanej wcześniej uczelni.

\section{Szkolenia}

Biblioteka Główna PWr jest organizatorem różnego rodzaju szkoleń i kursów: szkoleń własnej kadry, praktyk dla bibliotekarzy z zewnątrz i studentów bibliotekoznawstwa oraz szkolenia użytkowników. Od wielu lat organizuje też kursy ogólnokrajowe. Na skalę ogólnopolską rozpoczęto regularne kursy szkoleniowe w latach 80. Cykl „Komputerowe systemy biblioteczno-informacyjne” cieszył się zainteresowaniem bibliotekarzy przez ponad 15 lat, od 1985 roku do 2000. Niesłabnącą popularnością cieszy się specjalistyczny kurs "Czasopisma elektroniczne", który po raz pierwszy zaproponowany został przez pracowników BG PWr w roku 2000 i w dalszym ciągu niemalże każdego roku odbywają się dwie jego edycje. Program kursu obejmuje wykłady oraz ćwiczenia praktyczne przy komputerach polegające głównie na wyszukiwaniu informacji w omawianych serwisach, zarówno płatnych, jak i w wolnym dostępie. Niezapomnianą dla uczestników atrakcją każdej edycji kursu jest wycieczka po Wrocławiu z przewodnikiem miejskim. 


\section{Co czeka Bibliotekę PWr w najbliższej przyszłości?}

W połowie 2013 roku planowane jest zakończenie budowy nowego obiektu PWr - Środowiskowej Biblioteki Nauk Ścisłych i Technicznych na potrzeby Innowacyjnej Gospodarki. Będzie to pierwsza w Polsce biblioteka bez książek drukowanych. Nowatorski projekt łączy funkcje informacyjne i naukowo-badawcze, opierając się na silnie rozbudowanej, nowoczesnej infrastrukturze informatycznej oraz najnowszych technologiach e-medialnych ${ }^{30}$.

Głównymi składnikami nowej biblioteki będą Dolnośląskie Centrum Informacji Naukowo-Technicznej (DCINT) oraz zespół laboratoriów naukowo-badawczych, takich jak: laboratorium tyfloinformatyczne, bazy i hurtownie danych, dostęp zdalny do cyfrowych zasobów bibliotecznych, ochrona i bezpieczeństwo repozytoriów cyfrowych. DCINT będzie reprezentowane przez istniejące w BG PWr agendy - Dolnośląską Bibliotekę Cyfrowa, Punkt Informacji Normalizacyjnej oraz Dział Własności Intelektualnej i Ochrony Patentowej znajdujący się obecnie poza strukturą BG. Oprócz tego powstaną nowe ośrodki, pracownie i agendy.

Środowisko bibliotekarskie PWr szykuje się do dużych zmian, które $\mathrm{w}$ przyszłości będą dotyczyły nie tylko innej organizacji pracy, ale głównie podejmowania nowych zadań i wyzwań. Ich realizacja wpisana w program Środowiskowej Biblioteki Nauk Ścisłych i Technicznych na potrzeby Innowacyjnej Gospodarki będzie wymagała zdobywania nowych kwalifikacji i umiejętności.

Ogrom pracy czeka osoby zajmujące się PR. Obecnie zadania te są rozproszone $\mathrm{w}$ wielu oddziałach $\mathrm{BG}$ i realizowane przez pracowników wytypowanych przez dyrekcję BG zgodnie z cechami osobowościowymi, wiedzą i kompetencjami. Oprócz ośrodka promocji ds. badań naukowych, który będzie wchodził w nową strukturę DCINT, potrzebny jest zespół, który będzie realizował działania PR związane z funkcją biblioteczno-informacyjną biblioteki.

Jasne sprecyzowanie celów marketingowych poprzedzone analizami (np. SWOT), badaniami opinii i potrzeb użytkowników, opracowanie strategii employer i internal branding to zadania długofalowe, lecz przynoszące wymierne efekty. Istotna będzie kontynuacja obecnie prowadzonych przedsięwzięć, tj.: przygotowywanie różnego rodzaju wydawnictw i publikacji, kontakty z mediami, organizacja konferencji, szkoleń, wycieczek,

${ }^{30}$ Środowiskowa Biblioteka Nauk Ścisłych i Technicznych na potrzeby Innowacyjnej Gospodarki [online], [dostęp: 20.01.2013], dostępny w internecie: http://www.inwestycjeunijne.pwr.wroc.pl/projekt_bibliotech,1011.dhtml. 
festiwali, wystaw i innych form promujących działalność biblioteki skupionej $\mathrm{w}$ jednej agendzie. Ważnym zadaniem byłoby $\mathrm{w}$ dalszym ciągu informowanie $\mathrm{w}$ mediach (nie tylko uczelnianych) o nowych usługach realizowanych w Środowiskowej Bibliotece Nauk Ścisłych i Technicznych na potrzeby Innowacyjnej Gospodarki, a także ich propagowanie. Planowane zmiany dotyczące witryny internetowej - inny układ treści, wprowadzenie nowych funkcjonalności umożliwiających łatwiejszy dostęp do informacji znajdujących się na stronie WWW (wersja mobilna) oraz zapoznanie się ze strukturą budynku (np. wirtualny przewodnik po bibliotece), szersze wykorzystanie zasobów elektronicznych biblioteki, wprowadzenie szkoleń $w$ formie e-learningowej dla wszystkich grup odbiorców czy zdalny kontakt z pracownikiem biblioteki (także po jej zamknięciu) przez narzędzia internetowe (GG, mail, skype) - to tylko przykłady, które można i powinno się zastosować w związku z nowym etapem, w jaki wkracza biblioteka PWr jako Środowiskowa Biblioteka Nauk Ścisłych i Technicznych na potrzeby Innowacyjnej Gospodarki.

\section{Zakończenie}

Specjaliści od wizerunku pracujący w dużych firmach doskonale wiedza, w jaki sposób prezentować swoje produkty i jak trafiać do różnych grup docelowych. Każda instytucja kształtuje swój wizerunek przez własne czyny, bez względu na to, czy robi to świadomie, czy nie. Dążenie do budowania pozytywnego wizerunku służy również ważnemu celowi, jakim jest zdobycie zaufania użytkowników i społeczeństwa oraz przekonanie o korzyściach płynących z funkcjonowania danej instytucji.

$\mathrm{W}$ artykule opisano niewielki wycinek z działalności PR prowadzonej w Bibliotece PWr. Biblioteka przez kilka dziesięcioleci wypracowała sobie dobra, solidną markę. Jest znana i ceniona nie tylko w kraju, ale także poza jego granicami. Obecnie w coraz szerszym zakresie biblioteki realizują swoje zadania w świecie wirtualnym. Taki cel wpisany jest w dużej mierze również w działalność nowej Środowiskowej Biblioteki Nauk Ścisłych i Technicznych na potrzeby Innowacyjnej Gospodarki. 


\title{
Creating an image of an academic and research library on the basis of the public relations approach. A case study for the library of Wrocław University of Technology
}

\begin{abstract}
Aвstract. The ambition to create a favourable image of an organization is not exclusively important for corporate or commercial companies. Building a fair and constructive relations with the environment has also become more and more crucial for non-profit organizations such as, for example, libraries. This article aims to present promotional services that are usually performed at a typical academic library. The first part of the article includes an introduction to the basic terms and notions related to public relations and image-creating activities. The library of Wrocław university of technology is the case example in a presentation of the endeavours aiming at an improvement of these relationships. The library has been successfully implementing a number of different public relations techniques for many years. Currently, the library faces new challenges following the completion, in 1913, of the new environmental science and engineering library, the first library in Poland that would offer its resources exclusively in electronic form.
\end{abstract}

KEY worDs: brand, promotional activities, academic library, social communication. 